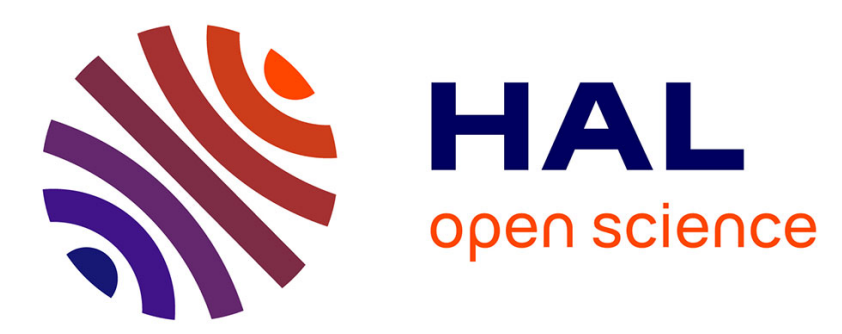

\title{
Regressing climate change, agricultural growth and food production on economic sustainability: gathering and analyzing data for ASEAN countries
}

Achmad Faqih, Mukarto Siswoyo

\section{- To cite this version:}

Achmad Faqih, Mukarto Siswoyo. Regressing climate change, agricultural growth and food production on economic sustainability: gathering and analyzing data for ASEAN countries. Journal of Security and Sustainability Issues, 2020, 10 (October), pp.194 - 205. 10.9770/jssi.2020.10.oct(14) . hal03121067

\section{HAL Id: hal-03121067 \\ https://hal.science/hal-03121067}

Submitted on 26 Jan 2021

HAL is a multi-disciplinary open access archive for the deposit and dissemination of scientific research documents, whether they are published or not. The documents may come from teaching and research institutions in France or abroad, or from public or private research centers.
L'archive ouverte pluridisciplinaire HAL, est destinée au dépôt et à la diffusion de documents scientifiques de niveau recherche, publiés ou non, émanant des établissements d'enseignement et de recherche français ou étrangers, des laboratoires publics ou privés. 
JOURNAL OF SECURITY AND SUSTAINABILITY ISSUES

ISSN 2029-7017/ISSN 2029-7025 (online)

2020 Volume 10 Number (October)

http://doi.org/10.9770/jssi.2020.10.Oct(14)

Scopus ${ }^{\circ}$

REGRESSING CLIMATE CHANGE, AGRICULTURAL GROWTH AND FOOD PRODUCTION ON
ECONOMIC SUSTAINABILITY: GATHERING AND ANALYZING DATA FOR ASEAN COUNTRIES

\author{
Achmad Faqih ${ }^{1}$, Mukarto Siswoyo ${ }^{2 *}$ \\ ${ }^{1,2}$ Universitas Swadaya Gunung Jati, Jl. Pemuda Raya No.32, Sunyaragi, Cirebon, Jawa Barat 45132, Indonesia \\ E-mail:*mukartosiswoyougj@gmail.com (Corresponding author)
}

Received 15 November 2019; accepted 29 June 2020; published 30 October2020

\begin{abstract}
The agricultural sector plays a great role in the economy of several countries and their economic sustainability is also majorly dependent on the agricultural performance of the country. There are various aspects related to agriculture sector that might have the impact on economic sustainability in one way or the other. In continuation of this issue, the researcher has conducted this study so that the impact casted by climate change, agricultural growth, and food production on the economic sustainability of the ASEAN countries can be studied effectively. For this research, the researcher has gathered relevant data from six ASEAN countries i.e. Brunei, Cambodia, Indonesia, Laos, Thailand, and Philippines. The period for which the data has been collected comprises of 29 years. For analysis of this data, the researcher has applied tests such as panel unit root test, panel cointegration test, AMG estimation and panel casualty test and has obtained the desired results. The results make it clear that the independent variables i.e. climate change, agricultural growth and food production have significant impact on economic sustainability for most of the selected ASEAN countries. Moreover, various variables have also shown unidirectional and bidirectional casualty among them.
\end{abstract}

Keywords: Climate Change; Agricultural Growth and Food Production; Economic Sustainability; ASEAN Countries

Reference to this paper should be made as follows: Faqih, A., Siswoyo, M. 2020. Regressing climate change, agricultural growth and food production on economic sustainability: gathering and analyzing data for ASEAN countries. Journal of Security and Sustainability Issues, 10(Oct), 194-205. http://doi.org/10.9770/jssi.2020.10.Oct(14)

Jel Codes: Q01

\title{
1. Introduction
}

The sustainability issue has its foundation in both the fields of science and economics (Guest, 2010). The context of economic sustainability refers to the sustained high growth by the governments in the form of solutions to the social and the financial issues. Rising up a sustainable economy under the paradigm of social, cultural and environmental crisis in the form of climate change is very challenging (Jänicke, 2012). As the world population is expected to cross 10 billion by the year 2050 (Nations, 2019; Specht et al., 2014), one of the most important goals of UN sustainable development is the eradication of hunger from the populations of the world countries by ensuring zero hunger levels by the year 2030. The drastic climate change around the globe has caused a rise in the temperatures and is the leading cause of droughts, heat waves, floods, storms and higher carbon emission in the atmosphere (Agovino, Casaccia, Ciommi, Ferrara, \& Marchesano, 2019). These changes and the increase in the demand for the food and other agricultural products have posed major challenge for achieving the objective of economic sustainability (Gliessman, 2014; Maleksaeidi \& Karami, 2013). The vulnerability of the countries for the changes in the climate, the associated production of the food and other agricultural products make it viable for these countries to adapt to the strategies that can help them cope with these issues and achieve economic sustainability (Ahmed, Thompson, \& Glaser, 2019). (See Table 1). 
Table 1: Share of Agriculture to total GDP in ASEAN countries in 2018

\begin{tabular}{ll}
\hline Country & GDP share (\%) \\
\hline Indonesia & 12.5 \\
\hline Malaysia & 7.3 \\
\hline Singapore & 0.5 \\
\hline Thailand & 6.2 \\
\hline Vietnam & 14.3 \\
\hline Laos & 14.5 \\
\hline Cambodia & 16.3 \\
\hline Myanmar & 24.6 \\
\hline Philippines & 8.1 \\
\hline Brunei & 0.8
\end{tabular}

The ASEAN (Association of South East Asian Nations) region is one of those which is badly affected from the climate changes as shown by the Climate Risk Index in which five of the top 25 countries, Thailand, Myanmar, Vietnam, Cambodia and the Philippines, belonged to the ASEAN region (Eckstein, Künzel, Schäfer, \& Winges, 2019; Khan, Y., et al., 2020). In a research on the ASEAN countries, the need for a national policy was highlighted which would incorporate strategies for controlling the adverse situation projected due to the climate change, improving the food production in these countries as the countries strive for the reduction of the harvesting loss and confirming the provision of food and the stability of the agricultural sector (Lassa, Lai, \& Goh, 2016). See Figure 1.

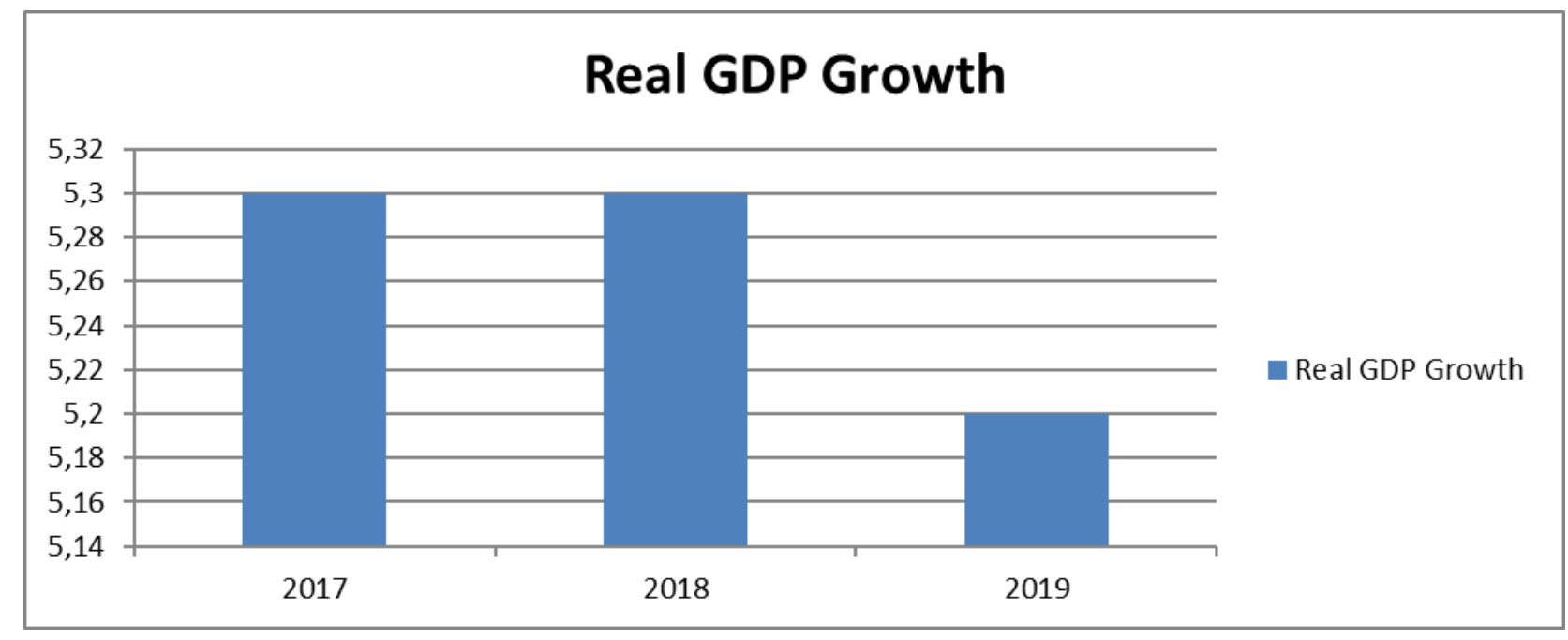

Figure 1: Real GDP growth (annual percentage change) in ASEAN countries

Studies have suggested that countries need to proactively develop policies and strategies to combat with the negative effects of climate change so that the growth in agriculture and food production can be enhanced to make the countries economically sustainable (Lassa et al., 2016; Nishimura, Ambashi, Iwasaki, \& Maeda, 2019; Tol, 2018; Hussain, S., et al., 2020). Hence, addressing this open research theme, the current paper has the primary aim of gathering and analyzing the data for the ASEAN countries by regressing the climate change, agricultural 
JOURNAL OF SECURITY AND SUSTAINABILITY ISSUES

ISSN 2029-7017/ISSN 2029-7025 (online)

2020 Volume 10 Number (October)

http://doi.org/10.9770/jssi.2020.10.Oct(14)

growth and food production on the economic sustainability. More specifically, this paper has the following research objectives:

- To evaluate the impact of Climate change on economic sustainability

- To evaluate the effect of agricultural growth on economic sustainability

- To evaluate the effect of food production on economic sustainability

This paper has significant contribution to the literature of sustainability by investigating the impact of climate change, food production and agricultural growth towards economic sustainability for the ASEAN nations. Practically, the current paper has contribution to building appropriate and effective policy recommendations for the governments of the countries for managing the climate change and optimizing the resources for food production and agricultural growth to make their economies prosper superiorly for sustainable development.

The structure of this paper is organized as ahead. The paper starts with the Introduction and moves forward to the literature review. Next, the research methodology and results are given. Based on these results, this paper concludes with discussion, research limitations and theoretical and practical implications of the study.

\section{Literature review}

\subsection{Climate Change}

Climate change is a big threat to the economic stability and the sustainability of a country (Ding et al., 2016; Huong, Bo, \& Fahad, 2019; Ninan \& Inoue, 2017; Moumen, El Idrissi, Tvaronavičienè, \& Lahrach, 2019. Mikhaylov, Moiseev, Aleshin, \& Burkhardt, 2020; Li, Yun, et al., 2020). The heat waves, as a result of the global warming, make it difficult for the people to work efficiently and hence the productivity is reduced. The unpredictable cyclones and the hurricanes damage the communities and devastate a large number of people who are affected from them and are left with poverty and other issues. The droughts destroy the farms and the harvests, which is projected to hinder the UN goal of fulfilling the food demands of the people. If the measures for controlling the climate change are not taken properly, then the negative effects of climate change are expected to forcibly push more than 100 million of the population into complete poverty by the year 2030. The climate change will be restraining the budget and the public debt system of the countries by disabling the economy through lower incomes and higher prices (Barange et al., 2014; Corrás-Arias, 2020; Ruth, Coelho, \& Karetnikov, 2007; Urry, 2015). Climate change disrupts the capacity of the natural resources which are utilized by the industries. For instance, the water resources are markedly reduced and it has detrimental impact on the major industries of power, oil, chemicals, fertilizer, textile, mining and metallurgy (Haseeb et al., 2021). The climate change also disturbs the energy and other resource patterns of their consumption. The increase in the air temperature demand more use of the water and other cooling technologies, hence the entire economical system is disturbed. This shows that in the long run, the changes in climate will negatively impact the society and the economy of countries, resulting in hotter and poorer states (Tol, 2018). From the early works of (McKay, 1980; Wigley, Richels, \& Edmonds, 1996; Zenghelis, 2006), the climate change is being considered as vigorously exerting negativity on the economic welfare for the long term. However, a climate change policy sensibly designed can help eradicate these effects (Goulder \& Mathai, 2000; Li, z. et al., 2020). The economic impacts of climate change are diverse and complex (Nordhaus, 2013; Wong, 2015) and need immediate attention (Tol, 2018). This discussion shows that the climate changes are substantially related to the economic sustainability, represented by the following hypothesis:

H1: Climate Change is significantly linked to economic sustainability

\subsection{Agricultural Growth}

The growth in the agricultural sector is the backbone for the progress of economy as it contributes a major portion to the country's GDP and ensures that the basic necessities are fulfilled for the mankind and can initiate the 
JOURNAL OF SECURITY AND SUSTAINABILITY ISSUES

ISSN 2029-7017/ISSN 2029-7025 (online)

2020 Volume 10 Number (October)

http://doi.org/10.9770/jssi.2020.10.Oct(14)

industrialization process for the country (Bartoli, Hamelin, Rozakis, Borzęcka, \& Brandão, 2019). Many developed countries have already availed its benefits. Hence, for the developing and least developed countries, it can play a strategic role for their economic development. Specifically, for those nations where the real income per capote is considerably low, the growth in agriculture can prove helpful. There are many ways in which agricultural growth can contribute to economic growth. Firstly, it provides the food to people and raw materials to the non- agricultural sectors of society. Secondly, it has the capability to create demand for the production of goods in the non- agricultural sector using the purchasing power of the rural population by enabling them to sell the extra goods in the market. Another benefit is that it can provide the investable surplus for investment into the non- agricultural sector. The growth in the agricultural sector can enable the country to earn the foreign revenue by exporting the surplus food and agricultural products. Lastly, it can bring the uneducated and non- skilled labor of the country to start earning by working in the agricultural activities and can reduce or alleviate poverty from the society. Hence, this sector can build up the economic capacity of a country and lead it towards sustainability (Ansari \& Khan, 2018; Hayat, Ali, Mateen, \& Bilal, 2019). However, the growth of Agriculture is confronted with three common challenges by the countries. The first challenge is the increase in the instability of the agricultural growth figures, where as the second challenge is the change in the geographical structure of agricultural production. The last challenge is the substantial rise in the agricultural costs (Ding et al., 2016). Hence, such technologies must be adapted so that the adverse effects of climate change can be mitigated and sustainable agricultural growth can be promoted (Tol, 2018). The growth in the agricultural production has many economic benefits and can highly foster regional economic development, however it is important to ascertain the non- economic effects, which include the extra use of water and the GHG emissions which need to be managed and controlled effectively (Sun et al., 2019). In a similar study carried out by (Sertoglu, Ugural, \& Bekun, 2017), the scholars have declared the agricultural sector to be a panacea for the country's economic progress and prosperity. The effective management of the agriculture system of a country promises its economy's success or loss. This study examined the effect of the agricultural sector growth on the economy of Nigeria using time series data (Haseeb et al., 2020). The results revealed that the country's GDP is highly dependent on the agricultural sector and its growth in the long run and the agricultural output has a positive relationship with the economic conditions. Hence, it is important that the government of the countries develop policies that aim at diversifying and allocating budget in this sector for economic sustainability (Sertoglu et al., 2017). These findings depict that the agricultural growth has positive links to the economic sustainability. Hence, this association can be shown as follows:

H2: Agricultural growth is significantly linked to economic sustainability

\subsection{Food Production}

The production of the food makes it possible for the country to feed its population on its own without importing food material from the foreign countries which has a major impact on the economy by the reservation of the foreign currency which otherwise would have been given in exchange for the food (DiCarolis et al., 2017). Studies by (Nair, 2018; Tait, Saunders, Guenther, \& Rutherford, 2016) also portrays the importance of food production for the sustainable economy. (Nishimura et al., 2019) has also emphasized on the value of harnessing various technologies by which the food production can be improved through modernizing the production processes and efficient utilization of the materials, so as to have lasting impact on the country's social and economic growth. In terms of the ever increasing population of the world, global efforts for increasing the food production and improving the agricultural sector are being made. These technological innovations and inventions have the capacity to make the food production sustainable. The ASEAN nations have devised a Work Plan for improving the economic status of these countries through various measures, like increase the volume of crops, the livestock and other food production through enforcing the use of modern farming practices to support the quality and the quantity of food (Yong \& Montesclaros, 2017). Hence, the support from government is needed to make sure that the country's food production remains stable and sustainable so that risks can be avoided and prices of food items can be stabilized for competitive market situation. Research is necessary to promote the food 
production to cope with the increasing demand. In case there gets an imbalance between the demand and supply of food, then the prices will fluctuate, incomes may fall and economic impact of food production can be questioned (Rossi, Johnson, Hendrickson, \& Scott, 2014; Upton, 1993). This discussion reveals that by increasing the food production, economic sustainability can be ensured and that a significant relationship can exist between them. So, this relationship is expressed in the following hypothesis:

H3: Food Production is significantly linked to economic sustainability

\section{Data and Methods}

\subsection{Data}

The motive behind the current study, as clear from the earlier sections, is to find out and analyze the impact that climate change, agricultural growth and food production impose on economic sustainability of ASEAN countries. The researcher has gathered relevant data from six ASEAN countries i.e. Brunei, Cambodia, Indonesia, Laos, Thailand and Philippines. The period for which the data has been collected comprises of 29 years. The major sources of data collection include World Bank Development Indicators and Global Economy which are considered to be the most authentic databases.

\subsection{Model Specification}

As far as the measurement units of variables of the study are concerned, the dependent variable i.e. economic sustainability has been measured suing an index named as index of sustainable economic welfare. In addition, the independent variable, climate change has been measured in context of the units of $\mathrm{CO} 2$ per million units of air. In the same way, the other independent variable, agricultural growth has been measured through the units of agricultural output per unit area. The last independent variable, food production has been measured through the production of crop per unit area. In addition to all the aforementioned variables, the researcher has also used a control variable i.e. population growth which has been measured through the number of people in a country. The following regression equation can be used in this regard;

$$
E S_{i t}=\alpha+\beta_{1} C C_{i t}+\beta_{2} A G_{i t}+\beta_{3} F P_{i t}+\beta_{4} P G_{i t}+\varepsilon_{i t}
$$

In this equation, $\mathrm{ES}$ represents economic sustainability, $\mathrm{CC}$ represents climate change, $\mathrm{AG}$ represents agricultural growth, FP represents food production, PG represents population growth. In the last, $\varepsilon_{i t}$ is the term that represents error.

\section{Estimation Procedure}

\subsection{Cross Sectional Dependence Test}

First of all, the cross sectional dependence test has been applied so that the cross dependent relations among the variables can be identified because without this test, the results might not be accurate (Breusch \& Pagan, 1980). This test has been used based on the following equation;

$C G_{B P}=T \sum_{i=1}^{N-1} \sum_{j=i+1}^{N} \widehat{P_{t j}^{2}}$

However, this model has a drawback that it cannot be used if $\mathrm{N}$ is vey large (Pesaran, 2004). So an alternative model can be used which is given as follows:

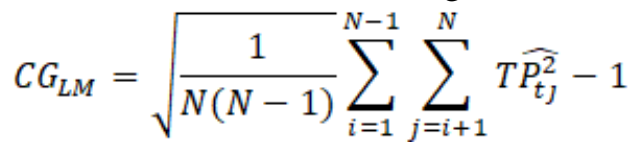


The null and alternate hypothesis are used in this test where the null hypothesis involves that no cross sectional dependence has been observed while alternate hypothesis involves that cross sectional dependence has been found. The rejection of null hypothesis is based on the p-value. Apart from this test, the researcher has used another test i.e. homogeneity test whose null hypothesis is based on homogeneous slopes while alternate hypothesis is based on heterogeneous slopes. MANUSCRIPT

\subsection{Panel Unit Root Test}

After cross sectional dependence and homogeneity test, panel unit root test has been employed by the researcher. The purpose of applying this test was to find out the order of integration of the variables and also to explain the stationary properties possessed by the variables. The researcher has used CIPS unit root test whose benefit is that it resolves the issue of cross sectional dependence found among variables (Pesaran \& Yamagata, 2008). The following equation can be used for this test:

$\Delta Y_{i, t}=a_{i}+b_{i} Y_{i, t-1}+c_{i} \bar{Y}_{t-1}+d_{i} \Delta \bar{Y}_{t}+e_{i, t}$

The version of the equation that considers the cross sectional dependence is as follows:

CIPS $=\frac{1}{N} \sum_{i=1}^{N} C_{i} A F_{i}$

In the above equation, CADF shows the cross sectional version of ADF test (Pesaran, 2007). The null hypothesis of this test presents that there is unit root in the data while it is non stationary. On the other hand, the alternate hypothesis presents that there is no unit root and the data is stationary.

\subsection{Panel Cointegration Test}

After the identification of order of integration and stationary properties of the collected data, the researcher has to explore of there is any cointegrated relationship between the variables or not. For this objective, the researcher has employed the panel cointegration test introduced by Westerlund and Edgerton. This test is named as LM bootstrap test of cointegration. Just like CIPS, this test also has the ability to resolve the issues regarding cross sectional dependence (Westerlund \& Edgerton, 2007). The following equation can be used for this test:

$L M_{N}^{+}=\frac{1}{N T^{2}} \sum_{i=1}^{N} \sum_{t=1}^{T} \widehat{w_{i}^{-2}} e_{i t}^{2}$

Just like unit root test, this test also has null and alternate hypothesis having the assumption of no cointegration and presence of cointegration respectively. The p-value is the decision maker of rejection of the null hypothesis. Moreover, for further estimating the cointegrated relationships between the variables, the researcher has used AMG estimation test so that the impacts of variables over one another can be identified.

\subsection{Panel Casualty Test}

Based on the cointegrated relationships, it was a possibility that there might be casual relationships between the variables as well, therefore the researcher has applied Kónya casualty test in this study. This test has the major benefit that it resolves the issues of cross sectional dependency between the variables. The null hypothesis involves no casualty while alternate hypothesis involve casual relationships (Kónya, 2006). The following equation can be used for this test:

$F S_{N, t}=\alpha_{2, N}+\sum_{i=1}^{l y 2} \beta_{2, N, i} O S_{N, t-1}+\sum_{i=1}^{l x 2} \delta_{2, N, i} F S_{N, t-1}+e_{2, N, t}$

\section{Results and Analysis}

\subsection{Results of Cross Sectional Dependence test}


The cross sectional dependence as well as homogeneity issues of the collected data were analyzed by applying the tests, the result of which has been given in table 1 . The values for $\mathrm{CD}_{\mathrm{BP}}, \mathrm{CD}_{\mathrm{LM}}$ and $\mathrm{CD}$ have been given separately for all the variables. It is very clear from the table that all the variables have rejected the null hypothesis that there is no cross sectional dependence among them. This leads to the result that all the variables of the study are cross dependent. On the other hand, the results of slope homogeneity represent that the values of botn delta and adjusted delta have rejected the null hypothesis and it leads to the conclusion that the coefficients of the study are heterogeneous. In this way, the results of both slope homogeneity and cross sectional dependence make the collected data favorable to enter the next phase of the research (Table 2).

Table 2: Cross-Section Dependence and Slope Homogeneity Tests Results

\begin{tabular}{llll}
\hline Variable & $C D_{B P}$ & $C D_{L M}$ & $C D$ \\
\hline ES & $183.203^{*}$ & $65.005^{*}$ & $29.299^{*}$ \\
CC & $172.100^{*}$ & $78.300^{*}$ & $35.204^{*}$ \\
AG & $166.103^{*}$ & $87.499^{*}$ & $38.394^{*}$ \\
FP & $153.532^{*}$ & $67.388^{*}$ & $46.388^{*}$ \\
PG & $180.394^{*}$ & $88.399^{*}$ & $25.394^{*}$ \\
\hline Slope Homogeneity Tests Results & & P-Value \\
\hline Tests & LM Statistics & t-value & .000 \\
Delta & 34.67 & 5.367 & .000 \\
Adj Delta & 29.87 & 4.887 & \\
\hline
\end{tabular}

\subsection{Results of Panel Unit Root Test}

After the basic tests i.e. slope homogeneity and cross sectional dependence, the researcher has applied CIPS test with the intention to explore the order of integration and stationarity of the variables. The results of this test can be viewed in the table 2. As per these results, the values for two series i.e. level and first difference has been given. It can be seen that at level series only four variables have rejected the null hypothesis of unit root of data and economic sustainability has accepted the null hypothesis. On the other hand, as soon as the researcher has first differenced the variables, it comes out that all the variables have rejected the null hypothesis of unit root of data. Thus it can be concluded that there is no unit root and the collected data is stationary and there is no unit root (Table 3).

Table 3: CIPS Panel Unit Root Test Results

\begin{tabular}{lll}
\hline Variable & At Level & First Difference \\
\hline ES & -2.993 & $-5.293^{* *}$ \\
CC & $-3.383^{*}$ & $-6.984 * *$ \\
AG & $-3.849^{*}$ & $-8.368 * * *$ \\
FP & $-5.349 *$ & $-9.392^{* *}$ \\
PG & $-4.229 *$ & $-8.838^{* *}$ \\
\hline
\end{tabular}

\subsection{Results of Panel Cointegration Test}

According to the results of LM bootstrap panel cointegration test presented in table 3 , it is evident that for both constant and constant plus trend, the p-value is less than the significant value leading towards the rejection of null hypothesis of no cointegration in both the cases. Thus it can be concluded that the variables of the study are having cointegrated relationships among them.

Table 4: LM Bootstrap Panel Cointegration Test Results

\begin{tabular}{lll}
\hline Conditions & LM statistics & Bootstrap p-value \\
\hline Constant & -4.387 & 0.846 \\
Constant + Trend & 2.497 & 0.872 \\
\hline
\end{tabular}

\subsection{Results of AMG Estimation}


JOURNAL OF SECURITY AND SUSTAINABILITY ISSUES

ISSN 2029-7017/ISSN 2029-7025 (online)

2020 Volume 10 Number (October)

http://doi.org/10.9770/jssi.2020.10.Oct(14)

The most crucial test of the study i.e. AMG estimation is having its results in the table 4 of the study. In this table, the coefficients and their rejection for all the countries selected for data collection purposes have been presented vividly. It can be seen that climate change has significant impact on economic sustainability for Brunei, Laos and Thailand while for the other three countries its impact is insignificant. As far as the impact of agricultural growth is concerned, its impact is significant on economic sustainability for all the selected ASEAN countries. In the same way, for food production, the impact on economic sustainability has been found as significant for all the countries except for Cambodia. In the last, the impact of population growth on economic sustainability is also significant for all the selected companies except for Indonesia. As far as the overall results are concerned, it is clear from the table that as the climate change changes by one percent, the economic sustainability will change by $27.7 \%$ overall. In the same way, with change in agricultural growth, food production and population growth, the economic sustainability will change by $45.2 \%, 45.6 \%$ and $45.4 \%$ respectively.

Table 5: AMG Estimation Results

\begin{tabular}{lllll}
\hline Countries & CC & AG & FP & PG \\
\hline Brunei & $0.204^{* *}$ & $0.168^{* *}$ & $0.265^{* *}$ & $0.246^{* *}$ \\
Cambodia & 0.097 & $0.145^{*}$ & 0.087 & $0.212^{* *}$ \\
Indonesia & 0.045 & $0.293^{* *}$ & $0.167 * *$ & 0.043 \\
Laos & $0.137 * *$ & $0.341^{* *}$ & $0.265^{* *}$ & $.0 .257^{* *}$ \\
Thailand & $0.178^{* *}$ & $0.262^{* *}$ & $0.273^{* *}$ & $0.232^{* *}$ \\
Philippines & 0.029 & $0.133^{* *}$ & $0.277^{* * *}$ & $0.363^{* *}$ \\
Penal & $0.277^{* *}$ & $0.452^{* *}$ & $0.456^{* * *}$ & $0.454^{* * *}$ \\
\hline
\end{tabular}

\subsection{Results of Casualty Test}

The pair wise results of casualty test have been given in the table 5 of the study. According to the table, economic sustainability and climate change have no casual relationship between them. However, economic sustainability and agricultural growth are having bidirectional casualty between them. Economic sustainability and food production are having unidirectional casualty running from economic sustainability to food production. In the same way, climate change and agricultural growth are also having unidirectional casualty running from agricultural growth to climate change. Similarly, climate change and food production are having unidirectional casualty running from climate change to food production. In the last, agricultural growth and food production are also having unidirectional casualty running from food production to agricultural growth.

Table 6: Kónya Panel Causality Test Results

\begin{tabular}{lll}
\hline Null Hypothesis: & F-Statistic & Prob. \\
\hline ES does not Granger Cause CC & 1.3293 & 0.0649 \\
CC does not Granger Cause ES & 3.2343 & 0.4391 \\
ES does not Granger Cause AG & 5.2994 & 0.0007 \\
AG does not Granger Cause ES & 8.3433 & 0.0000 \\
ES does not Granger Cause FP & 4.2033 & 0.0033 \\
FP does not Granger Cause ES & 3.2994 & 0.3124 \\
CC does not Granger Cause AG & 3.2043 & 0.0532 \\
AG does not Granger Cause CC & 5.2943 & 0.0053 \\
CC does not Granger Cause FP & 7.2033 & 0.0042 \\
FP does not Granger Cause CC & 2.2843 & 0.2044 \\
AG does not Granger Cause FP & 2.0294 & 0.2944 \\
FP does not Granger Cause AG & 4.8284 & 0.0058 \\
\hline
\end{tabular}


JOURNAL OF SECURITY AND SUSTAINABILITY ISSUES

ISSN 2029-7017/ISSN 2029-7025 (online)

2020 Volume 10 Number (October)

http://doi.org/10.9770/jssi.2020.10.Oct(14)

\section{Discussion and Conclusion}

\subsection{Discussion}

Three hypotheses have been made by the researcher based on the past literature so that these hypotheses can be tested using various techniques and tools. These hypotheses have been made based on the purpose of the current study i.e. to find out the impact casted by climate change, agricultural growth and food production on the economic sustainability of the ASEAN countries. In this regard, the first hypothesis that climate change has significant impact on economic sustainability of ASEAN countries has been accepted as the impact of climate change has been found significant for most of the countries selected. When the climatic conditions get better, it enhances the productivity of crops and other agricultural outputs and thus enhances the economic sustainability. This result is consistent with the past literature and can be explained on this basis (Clapp, Newell, \& Brent, 2018). The next hypothesis was that agricultural growth has significant impact on economic sustainability of ASEAN countries and this hypothesis has also been accepted because the results have indicated that agricultural growth has significant impact in all the selected ASEAN countries. When the agricultural growth increases, it not only fulfills the needs of the local people but the exports are also increased resulting in the enhancement of economic sustainability. This result is in accordance with the similar studies and researches that have been conducted in the past by various researchers (Azam \& Shafique, 2017). The last hypothesis was that food production has significant impact on economic sustainability of ASEAN countries. As the results have shown that this impact is significant for most of the selected countries, it can be stated that this hypothesis is also accepted. When the food production increases, the exports of the country are also increased providing growth and development to the economy of the country. This result is also in concordance with the past literature (Nepal \& Paija, 2019; Tait et al., 2016). Moreover, the researcher has also added a control variable i.e. population growth and its impact have also been found as significant.

\subsection{Conclusion}

In order to achieve the objective of the current study i.e. to find out the impact casted by climate change, agricultural growth and food production on the economic sustainability of the ASEAN countries, the researcher collected 29 years data from six ASEAN countries about the concerned variables and applied a number of appropriate and essential tests and tools for analysis purpose. The results have indicated that the impact of all the independent variables i.e. climate change, agricultural growth and food production have significant impact on economic sustainability in most of the selected ASEAN countries. The the conclusion can be drawn on the basis of these results that the agricultural sector must take steps to enhance the agricultural growth and food production. Moreover, the environment must be kept pollution free to bring positive changes in it so that the economy of the country might growth and develop leading towards the economic sustainability.

\section{Implications and Limitations}

As far as the practical implication of the study is concerned, it has information and guidance for the agricultural sector to improve their practices by various means to promote economic sustainability. In addition, it will also provide guidance about the making of policies and regulations to enhance agricultural growth and food production and also to bring positive changes in the climate to enhance economic sustainability. Theoretically, it will provide literature to the researchers and authors about the particular aspects used in the current study that might be helpful for further research. The sample size of the study is 29 and it is recommended for the other researchers to increase the sample size to get better results. The countries and regions other than ASEAN must be considered so that their context can also be covered for the study. 
JOURNAL OF SECURITY AND SUSTAINABILITY ISSUES

ISSN 2029-7017/ISSN 2029-7025 (online)

2020 Volume 10 Number (October)

http://doi.org/10.9770/jssi.2020.10.Oct(14)

\section{References}

Agovino, M., Casaccia, M., Ciommi, M., Ferrara, M., \& Marchesano, K. (2019). Agriculture, climate change and sustainability: The case of EU-28. Ecological Indicators, 105, 525-543.

https://www.sciencedirect.com/science/article/abs/pii/S1470160X18303170

Ahmed, N., Thompson, S., \& Glaser, M. (2019). Global aquaculture productivity, environmental sustainability, and climate change adaptability. Environmental management, 63(2), 159-172.

https://link.springer.com/article/10.1007/s00267-018-1117-3

https://ucpmr1.ucp.edu.pk/index.php/UCPMR/article/view/24

Ansari, S. A., \& Khan, W. (2018). Relevance of Declining Agriculture in Economic Development of South Asian Countries: An Empirical Analysis. AGRIS on-line Papers in Economics and Informatics, 10(665-2018-3620), 3-14.

https://ageconsearch.umn.edu/record/276108/

Azam, A., \& Shafique, M. (2017). Agriculture in Pakistan and its Impact on Economy. A Review. Inter. J. Adv. Sci. Technol, 103, 47-60.

Barange, M., Merino, G., Blanchard, J., Scholtens, J., Harle, J., Allison, E., . . Jennings, S. (2014). Impacts of climate change on marine ecosystem production in societies dependent on fisheries. Nature Climate Change, 4(3), 211-216.

https://www.nature.com/articles/nclimate2119?page=3

Bartoli, A., Hamelin, L., Rozakis, S., Borzęcka, M., \& Brandão, M. (2019). Coupling economic and GHG emission accounting models to evaluate the sustainability of biogas policies. Renewable and Sustainable Energy Reviews, 106, 133-148.

https://www.sciencedirect.com/science/article/pii/S1364032119301248

Breusch, T. S., \& Pagan, A. R. (1980). The Lagrange multiplier test and its applications to model specification in econometrics. The Review of Economic Studies, 47(1), 239-253.

Clapp, J., Newell, P., \& Brent, Z. W. (2018). The global political economy of climate change, agriculture and food systems. The Journal of Peasant Studies, 45(1), 80-88.

https://www.tandfonline.com/doi/abs/10.1080/03066150.2017.1381602

Corrás-Arias, M. Á. (2020). Determinantes de la banca extranjera en España. Un análisis por país de origen. Cuadernos de Economía, 43(121).

DiCarolis, J., Haab, T., Plakias, Z., Sheldon, I., Sohngen, B., \& Trinoskey, K. (2017). The Economic Contribution of Agricultural and Food Production to the Ohio Economy: The Ohio State University-College of Food, Agricultual, and Environmental ....

Ding, Y., Mu, M., Zhang, J., Jiang, T., Zhang, T., Wang, C., . . Z Zhang, S. (2016). Impacts of Climate Change on the Environment, Economy, and Society of China Climate and Environmental Change in China: 1951-2012 (pp. 69-92): Springer.

https://link.springer.com/chapter/10.1007/978-3-662-48482-1_4

Eckstein, D., Künzel, V., Schäfer, L., \& Winges, M. (2019). Global Climate Risk Index 2020. Bonn: Germanwatch.

Gliessman, S. R. (2014). Agroecology: the ecology of sustainable food systems: CRC press.

Goulder, L. H., \& Mathai, K. (2000). Optimal CO2 abatement in the presence of induced technological change. Journal of Environmental Economics and Management, 39(1), 1-38.

Guest, R. (2010). The economics of sustainability in the context of climate change: An overview. Journal of World Business, 45(4), 326335.

Haseeb, M., Kot, S., Hussain, H.I., Kamarudin, F. (2021) The Natural Resources Curse-Economic Growth Hypothesis: Quantile-onQuantile Estimations Evidence from Top Asian Economies, Journal of Cleaner Production, $279,123596$. https://doi.org/10.1016/j.jclepro.2020.123596

Haseeb, M., Kot, S., Hussain, H.I. and Jermsittiparsert, K. (2020) The dynamic nonlinear effect of urban intensity on natural resources in Indonesia: Evidence from asymmetric ARDL and Causality approaches, Acta Montastica Slovaca, 25 (2), 201 - 212. https://doi.org/10.46544/AMS.v25i2.7.

Hayat, U., Ali, S., Mateen, A., \& Bilal, H. (2019). The role of agriculture in poverty alleviation: Empirical evidence from Pakistan. Sarhad Journal of Agriculture, 35(4), 1309-1315.

Hussain, S., Shahzad, M., \& Shafiq, Z. (2020). Influence Of Indian Lobby On The Policymaking Of The United States Towards Pakistan. Hamdard Islamicus, 43(2.), 312-323.

Huong, N. T. L., Bo, Y. S., \& Fahad, S. (2019). Economic impact of climate change on agriculture using Ricardian approach: A case of northwest Vietnam. Journal of the Saudi Society of Agricultural Sciences, 18(4), 449-457.

https://www.sciencedirect.com/science/article/pii/S1658077X17304290

Jänicke, M. (2012). “Green growth”: from a growing eco-industry to economic sustainability. Energy policy, 48, 13-21. 
JOURNAL OF SECURITY AND SUSTAINABILITY ISSUES

ISSN 2029-7017/ISSN 2029-7025 (online)

2020 Volume 10 Number (October)

http://doi.org/10.9770/jssi.2020.10.Oct(14)

Kónya, L. (2006). Exports and growth: Granger causality analysis on OECD countries with a panel data approach. Economic Modelling, 23(6), 978-992.

Khan, Y., Hussain, A., \& Shah, N. H. (2020). Analysis Of Pakistan's Mutual Fund Performance Evidence From Traditional \& Modern Methods. Hamdard Islamicus, 43(2.), 296-311.

https://www.sciencedirect.com/science/article/abs/pii/S0264999306000496

Lassa, J. A., Lai, A. Y.-H., \& Goh, T. (2016). Climate extremes: an observation and projection of its impacts on food production in ASEAN. Natural hazards, 84(1), 19-33.

Li, Yun, Wang, K., Ji, X. M., \& Tang, Y. (2020). Financial psychology analysis of numerical superstitions and stock price volatility: Empirical evidences from China's A-share market. Revista Argentina de Clinica Psicologica, 29(1), $279-289$. https://doi.org/10.24205/03276716.2020.37

Li, Z. (2020). Psychological analysis of consumers' purchase behavior in sports market. Revista Argentina de Clinica Psicologica, 29(1), 228-234. https://doi.org/10.24205/03276716.2020.30

Maleksaeidi, H., \& Karami, E. (2013). Social-ecological resilience and sustainable agriculture under water scarcity. Agroecology and sustainable food systems, 37(3), 262-290.

https://www.tandfonline.com/doi/abs/10.1080/10440046.2012.746767

Mikhaylov, A., Moiseev, N., Aleshin, K., \& Burkhardt, T. 2020. Global climate change and greenhouse effect. Entrepreneurship and Sustainability Issues, 7(4), 2897-2913. http://doi.org/10.9770/jesi.2020.7.4(21)

Moumen, Z., El Idrissi, N.E.A., Tvaronavičienè, M., \& Lahrach, A. 2019. Water security and sustainable development. Insights into Regional Development, 1(4), 301-317. https://doi.org/10.9770/ird.2019.1.4(2)

McKay, G. (1980). Proceedings of the World Climate Conference, A Conference of Experts on Climate and Mankind: JSTOR.

Nair, T. (2018). Climate Change and Food Insecurities: Destabilisers of ASEAN Centrality? International Security in the Asia-Pacific (pp. 307-330): Springer.

https://link.springer.com/chapter/10.1007/978-3-319-60762-7_13

Nations, U. (2019). World population prospects 2019.

Nepal, R., \& Paija, N. (2019). Energy security, electricity, population and economic growth: The case of a developing South Asian resource-rich economy. Energy policy, 132, 771-781.

https://www.sciencedirect.com/science/article/abs/pii/S0301421519303581

Ninan, K. N., \& Inoue, M. (2017). Building a climate resilient economy and society: Challenges and opportunities: Edward Elgar Publishing.

Nishimura, H., Ambashi, M., Iwasaki, F., \& Maeda, M. (2019). Harnessing New Technologies for Social and Economic Progress Towards ASEAN 20401. Published in March 2019, 50.

Nordhaus, W. D. (2013). The climate casino: Risk, uncertainty, and economics for a warming world: Yale University Press.

Planas, A., Reig, F., Palmi, J., Del Arco, I., \& Prat, J. A. (2020). Motivations, barriers and physical condition in adolescents, according to the stage of change in physical exercise. Revista de Psicologia del Deporte, 29(2), 125-134.

Pesaran, M. H. (2004). General diagnostic tests for cross section dependence in panels.

Pesaran, M. H. (2007). A simple panel unit root test in the presence of cross-section dependence. Journal of applied Econometrics, 22(2), 265-312.

https://onlinelibrary.wiley.com/doi/full/10.1002/jae.951

Pesaran, M. H., \& Yamagata, T. (2008). Testing slope homogeneity in large panels. Journal of econometrics, 142(1), 50-93.

Rossi, J., Johnson, T. G., Hendrickson, M., \& Scott, J. (2014). The Economic Impacts of Local Food Production and Sales.

Ruth, M., Coelho, D., \& Karetnikov, D. (2007). The US economic impacts of climate change and the costs of inaction.

Sertoglu, K., Ugural, S., \& Bekun, F. V. (2017). The contribution of agricultural sector on economic growth of Nigeria. International Journal of Economics and Financial Issues, 7(1), 547-552.

Specht, K., Siebert, R., Hartmann, I., Freisinger, U. B., Sawicka, M., Werner, A., . . Dierich, A. (2014). Urban agriculture of the future: an overview of sustainability aspects of food production in and on buildings. Agriculture and human values, 31(1), 33-51.

https://link.springer.com/article/10.1007\%252Fs10460-013-9448-4

Sun, S., Yin, Y., Wu, P., Wang, Y., Luan, X., \& Li, C. (2019). Geographical evolution of agricultural production in China and its effects on water stress, economy, and the environment: the virtual water perspective. Water Resources Research, 55(5), 4014-4029.

Tait, P., Saunders, C., Guenther, M., \& Rutherford, P. (2016). Emerging versus developed economy consumer willingness to pay for environmentally sustainable food production: A choice experiment approach comparing Indian, Chinese and United Kingdom lamb consumers. Journal of Cleaner Production, 124, 65-72.

https://www.sciencedirect.com/science/article/abs/pii/S0959652616002699

Tol, R. S. (2018). The economic impacts of climate change. Review of environmental economics and policy, 12(1), 4-25.

Upton, M. (1993). The economics of food production. Paper presented at the Ciba Foundation symposium.

Urry, J. (2015). Climate change and society Why the social sciences matter (pp. 45-59): Springer.

Westerlund, J., \& Edgerton, D. L. (2007). A panel bootstrap cointegration test. Economics Letters, 97(3), 185-190.

Wigley, T. M., Richels, R., \& Edmonds, J. A. (1996). Economic and environmental choices in the stabilization of atmospheric CO 2 concentrations. Nature, 379(6562), 240-243.

https://www.nature.com/articles/379240a0 
JOURNAL OF SECURITY AND SUSTAINABILITY ISSUES

ISSN 2029-7017/ISSN 2029-7025 (online)

2020 Volume 10 Number (October)

http://doi.org/10.9770/jssi.2020.10.Oct(14)

Wong, K. V. (2015). Climate change: Momentum Press.

Yong, O. K., \& Montesclaros, J. (2017). Future of Agriculture and Implications for ASEAN.

Zenghelis, D. (2006). Stern Review: The economics of climate change. London, England: HM Treasury, 686-702.

Achmad FAQIH

ORCID ID: https://orcid.org/0000-0001-9340-8440

Mukarto SISWOYO

ORCID ID: https://orcid.org/0000-0002-9989-0810

This work is licensed under the Creative Commons Attribution International License (CC BY). http://creativecommons.org/licenses/by/4.0/

c) (7) Open Access 